\title{
When Methodology Beats Techniques; or, Why We Prefer Discourse and Narrative Analysis to Interpret Textual Data
}

\author{
Irina Trotsuk \\ Associate Professor, Peoples' Friendship University of Russia \\ Address: Miklukho-Maklaya Str., 10/2, Moscow, Russian Federation 117198 \\ E-mail: irina.trotsuk@yandex.ru
}

\begin{abstract}
Recently, textual analysis has become quite popular in social sciences in general, and in sociological studies in particular, partly due to the "narrative turn" that emphasizes the textual nature of all social practices and legitimizes their explanations through discourses that constitute social reality and identification models in contemporary society. Though content analysis has long ago proved its methodological and technical relevance to solve sociological questions in providing both qualitative and quantitative data about discursively structured social reality, the modern popularization of textual analysis within sociology is associated with two vague and multifaceted approaches, those of narrative and discourse analysis. The article first outlines the three types of sociological data the researchers have to deal with: formalized data that can be arranged in different matrices and analyzed mathematically; weakly formalized, but still structured and organized data; and non-formalized data that supposes the application of textual analysis. The author then presents her explanation of the current state of affairs in the use of textual analysis in empirical sociological studies, in which narrative and discourse analysis are often positioned as the only possible research methods to be employed despite several decades of the successful application of content analysis. This explanation consists of two parts: the first section includes a number of strict requirements a researcher must follow while conducting content analysis, while the second consists of the attractive advantages of narrative and discourse analysis as determined by their interdisciplinary status, nature, and origin.
\end{abstract}

Keywords: textual analysis, textual data, semi- and non-formalized data, content analysis, narrative analysis, discourse analysis, limitations and advantages of method

\section{What types of data do we have to deal with?}

Within empirical studies, it is generally known that sociologists deal with three types of data. The first type is formalized ${ }^{1}$ data that can be arranged in different matrices and analyzed mathematically (e.g., responses to closed-ended questions, indicators of the state's statistics, etc.). This type of data does not require or allow qualitative analysis, for there is nothing to apply it to. Social scientists often have to deal with the second type of data - "weakly formalized" data, i.e. structured and organized texts (e.g., responses to open-ended questions, non-finished sentences technique, the twenty statements test,

(c) Trotsuk I., 2015

(c) Centre for Fundamental Sociology, 2015

1. I prefer to name data formats using the word "formalization" not "structure" for the first one points to the type of data as it is, while the latter emphasizes the specific belief of the textual analysis adherents that every text does have some structure - either proposed by the author or "detected" by the researcher. 
etc.), that provide little data of the predictable structure per respondent. Even given a significant sample size, we increase not the diversity of meanings, but the frequencies of similar answers to the same questions. The third type of data is the main source of non-formalized data that supposes application of textual analysis techniques to in-depth interviews and semi-formalized written (auto)biographies, all kinds of narratives, and some types of personal documents, including visual, etc. Obviously, the third type of data gives sociologists much more analytical freedom than the second type due to its content and structure, but from the textual analysis point of view semi-, weakly-, or nonstructured data (texts) are basically the same.

Whether we like it or not, the first type - formalized data - is an absolute favorite of the sociological community, its beloved child, metaphorically-speaking, judging by how much attention and discussions are devoted to its procurement, analysis, and validation. Even without conducting the simplest content analysis of sociological articles on methodological and technical issues or results of empirical studies, one can confidently state that (mass) surveys form its thematic core and are a constant cause of sincere professional and personal concern. Following our metaphor, semi- or weakly-formalized data is a stepchild: fewer articles are devoted to the issues of its procurement, analysis, validation, and interpretation than in the case of formalized data. Moreover, such publications are often somewhat forced by nature. There are cases when one just cannot deal without relevant techniques, even in mass surveys, and if one cannot completely give up weakly formalized data, it is necessary to ensure the effectiveness of the relevant techniques. Then, the non-structured type of data is probably a sociological orphan, judging by the attention to the technical aspects of obtaining it, its analysis, validation, and interpretation. This is true at least in Russian tradition, although Western publications also tend to focus on qualitative methodology in the fundamental and applied senses as a whole, rather than the techniques to work with this type of data.

One could argue that there is no need to devote much attention to semi- and nonstructured data for there is, generally speaking, no difficulties in obtaining it (we all live among interviews/talks and written texts), and analyzing it (no doubt, all that could be said about content-analysis has already been said). This is a quite convincing suggestion, but there are much more serious grounds in ignoring content analysis in comparison with vague, polysemantic and umbrella-like narrative analysis and discourse analysis that have become extremely popular in the humanities and social sciences at least two and a half decades ago. However, narrative analysis and discourse analysis still defiantly lack precise definitions and are interpreted quite arbitrarily based on the conceptual and methodological preferences of the researcher, as well as the goals and objectives of the particular research. I suggest to divide these grounds into two groups, the "musts" and the "lets." 


\section{What "musts" of content analysis make it so "unattractive"?}

The first group of grounds that can explain the ignoring of content analysis and preferring narrative and discourse analysis is easily described. This explanation consists of the requirements that a researcher must fulfill so as not to be accused of producing some original discursive collages instead of scientific texts and not being criticized for incompetence while conducting content analysis. The list of such requirements includes writing a program of the research, constructing a sample of texts, developing measurement tools by analogy with a mass survey questionnaire, controlling the number and "quality" of categories, the preparation of all necessary technical and analytical documentation, etc. (see, e.g.: Berelson, 1952; Holsti, 1969; Krippendorf, 1980; Neuendorf, 2002; Weber, 1990; Woodrum, 1984). These are well-known "musts" of content analysis, or "textual coding," as an objective quantitative method of "translating" textual information into countable codes.

Undoubtedly, there are such open questions as what to do if one is not aware enough of some new or previously little-studied phenomenon to develop a coding scheme; what degree of coding procedures formalization is sufficient to have the right to name one's work content-analytical: should one take the type of content analysis (pragmatic, semantic, psychological - see, e.g., Vincent, 2000; traditional frequency model and non-frequency model - see, e.g., Tarshis, 2002, 2012, 2014) into account, or perhaps attempts to classify different versions of the method do not have sense at all, etc. However, the unresolved issues do not affect or cancel the basic "musts" of content analysis mentioned above and determined by its "status" of a scientific method for studying all types of texts "based on the criteria of reproducibility of results of the research" and not the "original, author's reading of the content of the text" (Tarshis, 2014: 14). Thus, it is quite difficult for a researcher to explain and justify one's decisions and procedures, especially sampling and coding choices, if he or she claims to conduct content analytical research.

However, it is not the "musts" of content analysis that deter sociologists. It is rather the "lets" of narrative and discourse analysis on the background of such "musts" that result in these two broad methodological approaches lacking conventional and generally accepted definitions, even though these are the absolute favorites of sociologists and representatives of other disciplinary fields as soon as it comes to analyzing and interpreting large volumes of textual data. So, let us try to introduce a review of the advantages, possibilities, and promises of narrative and discourse analysis that make them so appealing once sociologists aim or have to say something important or smart about non- or weakly-formalized data, regardless of falling into some "blind" or "white spots" on the map of sociological methodology ${ }^{2}$.

To make my arguments sound more comprehensible and convincing, I will combine the enticing features of narrative and discourse analysis into several groups. Firstly, un-

2. Given that we take for granted that narrative and discourse analysis are sociological approaches; otherwise we would spend a lot of efforts and time in a desperate struggle with other disciplines for their sociological affiliation. 
like content analysis that has never been doubted for being sociological enough, narrative and discourse analysis are free from any disciplinary fetters, and, therefore, let sociologists use all available methodological principles and technical procedures regardless of their disciplinary affiliation, thus proving to be truly interdisciplinary approaches. Secondly, narrative and discourse analysis expand the possibilities of researchers within the sociological science boundaries, for there are no restrictions here of what and how to study, unlike content analysis in the classical interpretation. Finally, being extremely catchall, narrative and discourse analysis possess some features that lets one incorporate them easily, albeit partly, into the qualitative approach in sociology which equips them with all the possibilities of the qualitative sociological research and strong disciplinary positions. Thereby, having almost no "musts" but a lot of "lets" in contrast to the content analysis method that possesses completely opposite qualities, narrative and discourse analysis have become extremely popular in today's sociology. I will express my opinion about this fact at the end of the article. I believe it is necessary first to provide a detailed review of the essence of the narrative and discourse approaches "lets" within sociological science.

\section{Why narrative and discourse analysis are so interdisciplinary?}

Due to the lack of works on textual analysis that can definitely be positioned as purely sociological literature, methodological bases of sociological work with textual data are not summarized in an explicit form. Such attempts to clarify and structure conceptual and terminological foundations of textual analysis are not even made in most books and studies. Therefore, if one claims to conduct narrative or discourse analysis, there are many interdisciplinary resources at one's full disposal without any requirement to justify their pure sociological application. For instance, interpretive and analytical problems related to the concept of "narrative" are discussed in a variety of disciplinary fields for narratology issues (see, e.g., Fludernik, 2009) can no longer be considered an exclusive domain of literature, and form an important part of philosophy, history, linguistics and sociology, whose representatives see in the narrative much more than just a "temporal structure," which, in the 1990's, resulted in the "narrative turn" that swept across humanities and social sciences (Tyupa, 2012: 75). For example, sociologists turn to philosophy which considers narratives as a method to obtain social identity, to objectify narrator's subjectivity and, simultaneously, to achieve certain social goals. In this case, narratives can take a few basic functional forms: the "narrative of stability" connects events and images in such a way that the narrator maintains a stable and unchanged self-esteem and self-identity; the "narrative of progress" explains events, roles or behavior of the narrator as undoubtedly desired and approved; and, the "narrative of regress," as completely opposite (Griffin, 2010: 133).

The most well known and "sociological" interpretation of narrative in philosophy was developed by J. Brockmeier and R. Harré (2001) in a critical perspective. They consider narrative a general category of linguistic production, which is too often used as if it was a 
word for identifying an ontology, whereas narrative is just a name for a number of regulations and standards within communication practices that organize and make sense of our everyday experiences, that is, a condensed set of rules that guarantee us social acceptance and successful actions within the framework of a given culture. Brockmeier and Harré question the idea that one narrative can be more or less true, or more or less accurate than another, and that the source of narrative's truthfulness lies in individual practices of introspection and self-reflection rather than in the social, historical, and cultural contexts in which these truths are produced (Bamberg, 2006). According to their critique, the notion of truthfulness must not be applied to narratives, for our actions, experiences, and lives are too fragmented, formless, and incomplete. It follows that narratives do not represent reality, but construct and constitute it by helping us to integrate any individual case of our personal life into the established and approved social and cultural scenarios. In other words, narratives are models of the world, and, at the same time, models of one's own "I." Narratives bind together personal and social modes of human life, they help one express one's emotions and opinions about what this world should be, and let one represent one's identity and society (Fraser, 2004: 180). As one gets older and accumulates a large baggage of life experiences and memories, narratives help one modify one's self-esteem and the extent of consent and embeddedness in the existing social order and discursive canon (Roberts, 2004: 12).

Thus, nobody will accuse one of not thinking sociologically if one refers to philosophical names, works, and concepts while developing a sociological interpretation of basic narrative problems such as the meaning and context. Any words, statements, and "stories" make sense due primarily to the context of their production and use. They do have some meaning by themselves, but somewhat different and insufficient for the sociological explanation of human actions; however, one should not and cannot reduce the meaning of narratives and discourses only to their contextual variations. The meaning of the words, phrases, sentences, the whole text they make, and the events they narrate can be significantly transformed beyond the dictionary or habitual borders in a variety of contexts. However, it does not mean that one all of a sudden makes a wonderful discovery especially when it comes to classical texts. Here, the newly discovered cultural meaning was initially sewn into the text, but before escaped one's sight (the "newness" is the result of one's former ignorance).

Another feature of the philosophical interpretation of narrative is an emphasis on its linguistic dimension. Narratives never describe/show/capture reality, but constitute and produce it in an (auto)biographical manner, inextricably linking textual descriptions and interpretations of one's own life experience and the world while combining carefully selected events in an unstable, changing, but coherent plot. Today, there is a special disciplinary branch labeled narratology (see, e.g., Manfred, 2002) that refers to the structuralist theory distinguishing, on the one hand, plot and the story, or discourse and the story, and on the other hand, text (or, more generally, discourse) and narrating or narration, i.e. "the act of narrating taken in itself" within the plot/discourse (Genette, 1980: 27). "Basically, a story refers to a skeletal description of the fundamental events in their natural 
logical and chronological order (perhaps with an equally skeletal listing of the roles of the characters in the story) ... It is the story - the chronological succession of events that provides the basic building blocks of narrative" (Franzosi, 1998). "The presence or absence of a story is what distinguishes narrative from nonnarrative texts" (RimmonKenan, 1983: 15). Neither explanation or description alone as specific linguistic genres is enough to constitute a narrative, although narrative, for its part, does not exclude any of them (Todorov, 1990: 28).

Post-structuralism expanded the boundaries of narrative analysis (Richardson, 2002: 415). It declared any "truth" not only to be narrative or discursive by nature, but pointed to every "truth" as a deliberate construction to support specific local, cultural, or political aspirations and, ultimately, to ensure claims to power. Two key ideas laid the conceptual foundations of post-structuralism: every text expresses ethical, ideological, and other of the author's views of reality, although neither the author nor the reader/listener should always be aware of such. Reality of the past is generated by the effect of the reality of the past, which creates seemingly irrelevant but the most rhetorically convincing parts of the text (Ankersmit, 2003b: 21-22). In other words, the key elements of the text that interest linguistics the most, those of narration, reflexivity and contextualization, determine the interdisciplinary character of narrative and discourse analysis, and equip a researcher with endless conceptual resources and technical possibilities without the risk of being accused of incompetence or breaking disciplinary boundaries.

Therefore, referring to the psychological or even psychoanalytical interpretations of narratives and discourses is no longer dangerous for sociologists. One of the definitions of psychoanalysis is "a set of interpretative strategies" (Ankersmit, 2003a: 333) focusing on the insignificant and irrelevant details of the narrative as markers of the patient's repressed and concealed emotions and knowledge. This definition further declares that it is difficult to separate a subjective version of events from some "objective truth," not because they are inextricably intertwined, but because the latter may not exist. Almost everything a person can theoretically tell his psychoanalyst has narrative form. Whether it is a simple description of events, retelling a dream or a fantasy, or attempting to turn one's life experience into some single thematic line, etc., we always try to create a metaphor of our personality with all the available linguistic tools. Nevertheless, there are two basic definitions of narrative in psychological tradition (Sarbin, 1986b), "wide," as a general term for naming the process of creating stories in general, and "narrow," as the name of a particular form of discourse different from all other ("report," "description," etc.). This is due to the mandatory presence of a conflict and its resolution, or a change of the status of the actor and/or situation in the course of the story. In the second case, in order for a text to become a narrative, a number of semantic criteria must be met. The temporal sequence of events responsible for the change in the situation must be represented, the spatial-temporal characteristics of any action mentioned must be clearly identified, all actors, both major and minor, must be labeled, the text must contain a kind of "summary" in the beginning and a "code" (a reference to the current state of affairs) at the end, and the text must contain the direct speech of actors in between (Labov, 2001). 
Regardless of the definition, wide or narrow, there are two basic approaches to the interpretation of narratives in psychology (Gerhardt, Stinson, 1994). The pragmatic approach claims that every narrative/story is contextually constructed, i.e., determined by the interaction in the given communicative situation. The affective approach explains the uniqueness of any narrative by the fact that every author offers and even imposes his own point of view replacing a simple chronologically ordered story (a retelling of events) by a narrative with a strong evaluative component. Thus, constructing narratives requires a high degree of narrative competence that develops as people grow up. It is approximately at the age of nine that evaluative components start to dominate in the previously chronologically-ordered retelling of events. As children grow older, stories become longer, more complicated, full of direct and indirect speech, more coherent, with obvious causal reasoning and explicit "definitions of the situation" (Rossiter, 1999: 61). In general, our ability to interpret the world increases as we master narratives and turn into mature "self-constructing animals" that can achieve self-understanding only through self-interpretation: we "think ... and make moral choices according to narrative structures” (Sarbin, 1986a: 8).

Perhaps, the most sociological interpretation of narrative was developed in the historical science. Narratives let us go beyond methodological limitations of the traditional historiography and to use the past available to us only in its linguistic representation to understand the present (Heise, 1995). The "linguistic turn" in history caused fierce debates between "traditional" historians seeing no demarcation line between historical writing and the past, and historians who emphasize the conventional and rhetorical construction of historical narratives, i.e. either we consider reality as completely permeable to history and turn it into an ideology, or, on the contrary, consider reality as absolutely impenetrable and turn it into a poetry (Barthes, 2000: 286). Both "types" of historian are addicted to narrative forms and rhetorical devices, because otherwise they cannot "capture" history and turn the past into a series of predictable episodes (Boedeker, 2010: 540).

The "narrative turn" in history sharpened the debates about the "truth" of narratives. Historians accepted the fact that we cannot change our past, but we can change a story of it (Dennett, 2003). These disputes ended with the recognition of the need to focus not on what did happen, but on what kind of metaphorical models one uses to describe what happened and how/why they became "convenient" to incorporate events of our private lives into the key values and structures of our culture and society (Croissant, 2003: 467). Even the most fundamentally oriented and "objective" textual reconstruction of the historical past inevitably creates a narrative that reflects not real time, but some conditional temporality, density of events, and causal sequence predetermined by the current social and cultural situation and its dominant ideology (Franzosi, 1998: 530). Thus, both in history and sociology, we must humbly admit that (a) there is no objective past, only its narrative representations open to rewriting; (b) not the facts but specific lexical and grammatical categories, and the social and cultural hierarchy of textual codes create narratives; (c) narrative interpretation of the past does not problematize it, but emphasizes the rhetorical mode of its constitution; and (d) the language of narrative is metaphorical, 
opaque, and autonomous. It introduces "names" as an interpretive tool for understanding the past, which, however, does not prevent narrative interpretations to turn into common concepts of everyday language and recognized conceptual models of social sciences (Ankersmit, 2003b: 44-130).

\section{Why narrative and discourse analysis are so multi- within sociology?}

The second group of the "lets" of narrative and discourse analysis is due to the freedom to combine a variety of methodological grounds without having to choose just one of them and justify one's decision. There are several reasons explaining such a freedom of an "irresponsible" choice. Firstly, sociology was among the last of the scientific disciplines to recognize the narrative nature of human experience and social reality. Therefore, it borrowed a lot of methodological "stuff" from the "pioneers," together with the accompanying conflicts, which resulted in the ongoing discussions within the sociological community (see, e.g., Labov, Waletzky, 1997). Secondly, the notions of "narrative" and "discourse" are generally accepted as "legitimate" characteristics of both respondent and sociologist other than description or logical and statistical explanation. Narratives are essentially temporal by structure, historical by design, and rhetorical by explanation mode (Griffin, 2010: 133). So, no less than everyday actors, sociologists are "narrators" (e.g., Ellerman, 1998; Ezzy, 1998; Fraser, 2004), telling "stories" to explain how they transform narratives of everyday actors and empirical objects into some spatial, temporal, and logical configurations (Campbell, 2002; Maines, 1993: 17). Thirdly, one can choose a broad definition of narrative as a metaphor for various forms of biographies that denies the possibility of systematic and precise methods of obtaining, transcription and analysis of narratives, i.e. one can interpret narrative as a synonym for biographical data and a general methodological orientation in the framework of the qualitative approach. It is also possible for one to prefer a rigid formalist and minimalist definition of narrative as a retelling of a particular moment in the past with a fixed set of structural elements helping to construct a coherent story. The last definition is most consistent with the empirical interpretation of narrative in sociological research as a series of individual statements, in which one is interested in discovering the strategy of combining past events into a convincing story (Maines, 1993: 47). However, none of the definitions possesses a heuristic priority, for they all emphasize that narratives and discourses constitute social order and the basic structures of our identity (Roberts, 2004: 10).

A sociological interpretation of narrative as a textual mode of personal (both the scientist and the ordinary person) and social life eliminates all traditional restrictions on the combination and choice of the conceptual framework to study social practices. In other words, we are to give up our idealistic illusion that we can find and demonstrate some real people in some real world, and accept the inevitability of multivariate and endless interpretive process and epistemological priority of common-sense knowledge in the form of narrative. Such an acceptance gives one an astonishing freedom in combining methodological approaches and techniques under the "label" of either narrative 
or discourse analysis, and explains largely why we love these two fellows so tenderly, regardless of their not-quite- sociological nature and origin. To qualify for conducting narrative analysis, it is sufficient to study real existing objects - recorded (oral, written, or visual) narratives - acting rather as literary critics, treating actions as texts, rather than as researchers, seeking to squeeze the unruly objective reality in the prepared beforehand and convenient schemes (Irwin, 1996: 109). Once there is a specific "object," the narratives, the choice of analytical tools and interpretive models depends solely on one's methodological priorities and interests, and on the tasks of the project. One can select a dramatic approach and "rewrite" a social interaction reflected in the narrative as a series of changing roles and identities, or a sociolinguistic approach focusing on syntax, semantics, punctuation, and other linguistic characteristics of text as markers of the social and cultural determination of the narrative (Abu-Akel, 1999: 437-438), or a structural approach, emphasizing the logical and chronological order of narrated events (Franzosi, 1998: 524; Labov, Waletzky, 1997). Another option is to combine elements of all three approaches, keeping in mind that our sociological analysis is nothing more than an advanced and rational "retelling" of everyday narratives (Langenohl, 2012: 40-42).

The same works for discourse analysis as an extremely multifaceted "umbrella-like" term (Hammersley, 2003), an amorphous metaphorical complex constituting a common thematic background and categorical contours of different studies. There are only three characteristics that unite a huge number of completely dissimilar studies under the label of discourse analysis: (1) the focus of interest (we seek or identify some discourse), (2) careful attention to the contextual conditions of creation and existence of textual objects, and (3) a refusal to separate the linguistic form and the content of events, for the social reality is constructed discursively, and texts represent both the reality and the ways of its perception and description. The continuity of discursive and non-discursive realities is emphasized within the discourse analysis by the concepts' "case" (the choice of language means depends on social conditions and purposes of communication), "cohesion" (links between elements of the text in its surface structure), and "coherence" (logic and semantic links in the text). The discourse determines the grammar, vocabulary, syntax, and semantics of texts that create a whole special world with its own rules of truth and etiquette.

Therefore, when we say "discourse," we appeal to different aspects of textual and extralinguistic reality without trying to draw a clear demarcation line between many methodological perspectives and formats of analytical work with textual data because they all come from the same postulate. Social reality is constructed linguistically, and all "texts" around us are social by nature. There are some basic differentiation lines in the field of discourse studies, which you can with equal success take into account or not. For example, there are three "traditional" version of discourse analysis: the most "sociological" (M. Foucault), considering discourse as an ideological style or way of "speaking"; the most "linguistic" (T. A. van Dijk), defining discourse as a structuring principle of any communication; and the most "semiological" (R. Barthes), based on the concept of myth. Foucault identifies four dimensions in every discourse, or "discursive forma- 
tions" - objects, modality, concepts, and thematic unity (Foucault, 1996a: 40) - and states that discourse is a way of submission and control by external procedures of exclusions and internal procedures of classification and ordering (Foucault, 1996b: 52, 65). Van Dijk suggests that we extract semantic blocks and fragments from discourse (stereotyped thematic repertoires determined by the communicative and cultural context as well as socio-demographic, role-playing and personal characteristics of the author), and compare them with the a priori given situational models to summarize the ideological position of the author (van Dijk, 1989: 45-6o). Barthes believes that any social "myth" (narrative or discourse) pretends to be an innocent representation rather than an explanation of the world, but its verbal/visual structure and intentional power convicts and defines an imperative response/certain reaction of the audience (Barthes, 2000: 247-281). Three types of discourse analysis are grouped under the label "traditional," for all emphasize the situational construction of the social world with a variety of discourses, thus focusing not on comparing semantic systems and the reality, but on studying practices of describing the world (Edwards, 1997: 45).

Another attempt to structure the field of discourse studies is presented in the book of L. Phillips and M. Jorgensen Discourse Analysis as Theory and Method (2002), who identify three types of discourse analysis: poststructuralist discourse theory of E. Laclau and Ch. Mouffe, discursive psychology, and critical discourse analysis of N. Fairclough. According to Laclau and Mouffe, discourses create social worlds with a set of meanings that interact with each other, and often fight for domination. As a result, we live not in the objective world of things, but in the mythical world of discursively set values (metaphors). Then, the task of discourse analysis is to show how values (metaphors) are created and constitute the society. Discursive psychology is considered the most empirically oriented approach interested in the peculiarities of the everyday use of language in social interaction. As such, the task of discourse analysis is to assess how flexibly/variably/creatively people (being both the results and creators of discourses) use existing social discourses to discuss their worldviews and to (re)create and modify the socio-cultural context. Critical discourse analysis developed by Fairclough also underlines an active role of discourse in the construction of social world, but clearly separates discourse as just one of many aspects of social reality from non-discourse (Fairclough, 1993).

The demarcation lines mentioned above are too vague, especially for empirical and applied sociological studies. I suggest distinguishing two models of discourse analysis, ascending and descending, rather than hopelessly try to explain one's methodological preferences. In the first case, not caring much about its representativeness, the researcher collects empirical data to reconstruct a basic scheme of particular type of texts (e.g., biographies of people with similar life experience) or social practices (e.g., verbal and visual representations of women in commercials). Sometimes such a model of discourse studies is considered a synonym of "qualitative research approach" (Cheek, 2004) for both seek to discover the discursive "frames" (syntactic, semantic, contextual, situational, etc.) that determine our vision of the world. The key indicator of such "frames" are metaphors (Steger, 2007) that create figurative speech and synthesize everyday knowledge into the gen- 
eral worldview while not allowing it to break up into unrelated fragments (Ankersmit, 2003a: 298). Within the descending logic of discourse analysis, the researcher tries to detect an a priori known type of discourse or evaluate its influence/dominance (e.g., racist or sexist discourse in the speeches of political leaders) using the three-dimensional model of a speech act (communicative event) as consisting of a text (with specific semantic, syntactic, and other features), discursive practices of producing such texts, and social reality producing such discursive practices (Fairclough, 1993).

\section{Why narrative and discourse analysis are a part of qualitative approach?}

Finally, we have reached the third group of narrative and discourse analysis "lets" that make them so convenient and attractive for sociologists. These two fellows are so similar to the theoretical and methodological positions with the biographical method and ethnography that they can be considered legitimate integral part of the qualitative approach in sociology. For instance, such similarities are obvious at the stage of obtaining narratives, that is, from the point of view of available techniques and the encountered problems. As a rule, regardless of the technique applied (written biography, narrative or semi-structured interview, etc.), the "life story" is a kind of "performance" of the narrator trying to fit his personal life trajectory in the broad social context. Therefore, in the framework of the biographical method narrative analysis focus on the linguistic features of the biographical "play" to discover the social identity of the narrator, and manifestations of the collective experience, typical and symptomatic behavior patterns, and life strategies. Narrative analysis and the biographical method are also similar in that they are not able to solve the problem of generalization, and claim that "the good research [reports and articles] should be read as narratives — as a whole" (Flyvbjerg, 2004).

I present another example. Ethnography and narrative analysis break (or rather ignore) the same standards of the "exact" science, those of reliability (cannot be guaranteed due to the interaction between researchers and informants), repeatability (observations and interviews are too local to be repeated precisely), and representativeness (there are no clear criteria for selecting data, and the number of cases is too small) (see, e.g., Gubrium, Holstein, 1999; Sanders, 1999). At the same time, the combination of the elements of narrative and ethnographic approaches can significantly improve the quality of analytical descriptions by their mutual control (Groarke, 2002: 565-568). Ethnographic attention to details allows to "see" those common "frames" (concepts, scenarios, values, etc.) that determine the structure, the content, and the very possibility of individual and group narratives, thus saving narrative analysis from critical attacks for its inability to describe large-scale social events, processes and macrostructures (Nathanson, 2009; Sakai, 2009). Narratives of personal experience, for their part, highlight the "nature" of the community not only as an objective fact of social reality, but also as a set of shared symbolic meanings that form the "life-world" of each of its members. Nevertheless, no combination of narrative, discursive, ethnographic, and biographical approaches can eliminate the three basic sources of bias and errors of textual analysis within qualitative research. These sources of 
bias and errors are the unavoidable subjectivity of the researcher, the "nature" of the data (memory problems, linguistic limitations, level of narrative competence, combination of true and false statements, etc.), and the respondents' intentions (we can be sure only in that they are never inclined to report everything that happened and deliberately omit the most sensitive topics).

I believe that the provided list of attractive possibilities of narrative and discourse analysis is a very convincing explanation of their popularity in sociology and far beyond, although an insufficient one. There is no doubt that social reality is a discursively created world that cannot claim authenticity, and there are milliards of subjective truths embodied in personal and group narratives. Therefore, the only thing left to social scientists seeking to discover the nature of a socially constructed and discursively constituted "lifeworld" is to focus on the typical textual strategies of the typical social actors in the typical institutional and local contexts, and to use all available resources of narrative and discourse analysis. There is also no doubt that, since social and personal realities have narrative character, the concepts of narratology can be applied far beyond its rather vague disciplinary borders, easily borrowed by and adapted to new research situations to detect narrative structures of all events and actions (chronotopic constitution, modality of representation, the "voice" of the narrator, etc.). However, at the same time, there is no doubt that if one wants to meet the strict standards of the scientific method while analyzing textual data, one must conduct content analysis to "objectify" results of narrative and discursive studies. The suggestion that sociologists prefer narrative and discourse analysis to content analysis because they are wider - we can use content analysis within these two at any step of the research, but not vice versa - is not convincing enough. I would rather dare to suggest that, within content analysis, one's professional incompetence and ideological biases are detected immediately, while within narrative and discursive studies, it is extremely hard to prove that one is doing something wrong. The latter is a distressing suggestion, so let us stick to the former.

\section{References}

Abu-Akel A. (1991) Episodic Boundaries in Conversational Narratives. Discourse Studies, vol. 1, no 4, pp. 437-453.

Ankersmit F. R. (2003a) Narrativnaja logika: semanticheskij analiz jazyka istorikov [Narrative Logic: A Semantic Analysis of the Historian's Language], Moscow: Idea-Press.

Ankersmit F. R. (2003b) Istorija i tropologija: vzlet i padenie metafory [History and Tropology: The Rise and Fall of Metaphor], Moscow: Kanon Plus.

Bamberg M. (2006) Stories: Big or Small: Why Do We Care? Narrative Inquiry, vol. 16, no 1, pp. 139-147.

Barthes R. (2000) Mifologii [Mythologies], Moscow: Sabashnikovs' Press. 
Berelson B. (1952) Content-Analysis in Communication Research, Glencoe: Free Press.

Boedeker H. E. (2010) Otrazhenie istoricheskoj semantiki v istoricheskoj kul'turologii [Reflection of the Historical Semantics in the Historical Cultural Studies]. Istorija ponjatij, istorija diskursa, istorija mentaliteta [History of Concepts, History of Discourse, History of Mentality] (ed. H. E. Boedeker), Moscow: Novoe literaturnoe obozrenie, pp. 5-17.

Brockmeier J., Harré R. (2001). Narrative: Problems and Promises of an Alternative Paradigm. Narrative and Identity: Studies in Autobiography, Self and Culture (eds. J. Brockmeier, D. Carbaugh), Amsterdam: John Benjamins, pp. 39-58.

Campbell R. A. (2002) A Narrative Analysis of Success and Failure in Environmental Remediation. Organization \& Environment, vol. 15, no 3, pp. 259-277.

Cheek J. (2004) At the Margins? Discourse Analysis and Qualitative Research. Qualitative Health Research, vol. 14, no 8, pp. 1140-1150.

Croissant J. L. (2003) Theory, Narrative, and Discipline at the Intersections of Science and Technology Studies and History. Bulletin of Science, Technology \& Society, vol. 23, no 6, pp. 465-472.

Dennet D. S. (2003) Pochemu kazhdyj iz nas javljaetsja novellistom [Why we all are novelists]. Voprosy Filosofii, no 2, pp. 121-130.

Edwards D. (1997) Discourse and Cognition, London: SAGE.

Ellerman A. (1998) Can Discourse Analysis Enable Reflective Social Work Practice? Social Work Education, vol. 17, no 1, pp. 35-44.

Ezzy D. (1998) Theorizing Narrative Identity: Symbolic Interactionism and Hermeneutics. Sociological Quarterly, vol. 39, no 2, pp. 239-252.

Fairclough N. (1993) Critical Discourse Analysis and the Marketization of Public Discourse: The Universities. Discourse \& Society, vol. 4, no 2, pp. 133-168.

Fludernik M. (2009) An Introduction to Narratology, London: Routledge.

Foucault M. (1996a) Arheologija znanija [Archeology of Knowledge], Kyiv: Nika-Center.

Foucault M. (1996b) Porjadok diskursa [The Order of Discourse]. Volja $k$ istine: Po tu storonu znanija, vlasti i seksual'nosti [Will to Know: Beyond Knowledge, Power and Sexuality], Moscow: Kastal, pp. 47-96.

Flyvbjerg B. (2004) Five Misunderstandings about Case-Study Research. Qualitative Research Practice (eds. C. Seale, G. Gobo, J. F. Gubrium, D. Silverman), London: SAGE, pp. 420-434.

Franzosi R. (1998) Narrative Analysis - or Why (and How) Sociologists Should Be Interested in Narrative. Annual Review of Sociology, vol. 24, pp. 517-554.

Fraser H. (2004) Doing Narrative Research: Analyzing Personal Stories Line by Line. Qualitative Social Work, vol. 3, no 2, pp. 179-201.

Genette G. (1980) Narrative Discourse: An Essay in Method, Ithaca: Cornell University Press.

Gerhardt J., Stinson Ch. (1994) The Nature of Therapeutic Siscourse: Accounts of the Self. Journal of Narrative and Life History, vol. 4, no 3, pp. 151-191. 
Griffin L. (2010) Istoricheskaja sociologija, narrativ i sobytijno-strukturnyj analiz: pjatnadcat' let spustja [Historical Sociology, Narrative and Event-Structural Analysis: Fifteen Years After]. Sociological Studies, no 2, pp. 131-140.

Groarke S. (2002) Psychoanalysis and Structuration Theory: The Social Logic of Identity. Sociology, vol. 36, no 3, pp. 559-576.

Gubrium J. F., Holstein J. A. (1999) At the Border of Narrative and Ethnography. Journal of Contemporary Ethnography, vol. 28, no 5, pp. 561-573.

Hammersley M. (2003) Conversation Analysis and Discourse Analysis: Methods or Paradigms? Discourse \& Society, vol. 14, no 6, pp. 751-781.

Heise D. R. (1995) Specifying Event Content in Narratives. Available at: http://www. indiana.edu/ socpsy/papers/EventContent.html (accessed 7 August 2015).

Holsti O. R. (1969) Content Analysis for the Social Sciences and Humanities, Reading: Addison-Wesley.

Krippendorf K. (1980) Content-Analysis: An Introduction to Its Methodology, London: SAGE.

Labov W. (2001) Uncovering the Event Structure of Narrative, Washington: Georgetown University Press.

Labov W., Waletzky J. (1997) Oral Wersions of Personal Experience: Three Decades of Narrative Analysis. Journal of Narrative and Life History, vol. 7, no 1-4, pp. 3-38.

Langenohl A. (2012) What Is the "Case"? Strategies of Generalization in Qualitative Sociology. Opyt i teorija: refleksija, kommunikacija, pedagogika [Experience and Theory: Reflection, Communication, Pedagogics] (ed. P. Safronov), Moscow: Delo, pp. 31-48.

Maines D. R. (1993) Narrative's Moment and Sociology's Phenomena: Toward a Narrative Sociology. Sociological Quarterly, vol. 34, no 1, pp. 17-38.

Manfred J. (2002) Narratology: A Guide to the Theory of Narrative, Part III: Poems, Plays and Prose: A Guide to the Theory of Literary Genres. Available at: http://www.unikoeln.de/ ameo2/ppp.htm (accessed 7 August 2015).

Nathanson C .A. (2009) Problems, Crises, Events and Social Change: Theory and Illustrations. Sociological Research Online, vol. 14, no 5. Available at: http://www.socresonline.org.uk/14/5/11.html (accessed 7 August 2015).

Neuendorf K. A. (2002) The Content Analysis Guidebook, Lonson: SAGE.

Roberts B. (2004) Konstruirovanie individual'nyh mifov [Constructing individual myths]. INTER, no 23, pp. 7-15.

Richardson L. (2002) Writing Sociology. Cultural Studies - Critical Methodologies, vol. 2, no 3, pp. 414-422.

Rimmon-Kenan S. (1983) Narrative Fiction: Contemporary Poetics, London: Routledge.

Rossiter M. (1999) A Narrative Approach to Development: Implications for Adult Education. Adult Education Quarterly, vol. 50, no 1, pp. 56-71.

Sakai T. (2009) Trans-generational Memory: Narratives of World Wars in Post-conflict Northern Ireland. Sociological Research Online, vol. 14, no 5. Available at: http://www. socresonline.org.uk/14/5/15.html (accessed 7 August 2015). 
Sanders C. R. (1999) Prospects for a Postpostmodern Ethnography. Journal of Contemporary Ethnography, vol. 28, no 6, pp. 669-675.

Sarbin T. (1986a) The Narrative as a Root Metaphor for Psychology. Narrative Psychology: The Storied Nature of Human Conduct (ed. T. R. Sarbin), New York: Praeger, pp. 3-21.

Sarbin T. R. (ed.) (1986b) Narrative Psychology: The Storied Nature of Human Conduct, New York: Praeger.

Steger T. (2007) The Stories Metaphors Tell: Metaphors as a Tool to Decipher Tacit Aspects in Narratives. Field Methods, vol. 19, no 1, pp. 3-23.

Tarshis E. (2002) Perspektivy razvitija metoda kontent-analiza [Perspectives of the content analysis method]. Sociology: Methodology, Methods, Mathematical Modeling, no 15 , pp. 71-92.

Tarshis E. (2012) Istoricheskie korni kontent-analiza: dva bazovyh teksta po metodologii kontent-analiza [Historical Roots of Content Analysis: Two Basic Texts on Methodology of Content Analysis], Moscow: URSS.

Tarshis E. (2014) Kontent-analiz: principy metodologii [Content Analysis: Methodological Principles], Moscow: URSS.

Todorov T. (1990) Genres in Discourse, New York: Cambridge University Press.

Tyupa V. (2012) O predmete narratologii [On the Subject of Narratology]. Opyt i teorija: refleksija, kommunikacija, pedagogika [Experience and Theory: Reflection, Communication, Pedagogics] (ed. P. Safronov), Moscow: Delo, pp. 75-96.

Van Dijk T. A. (1989) Jazyk. Poznanie. Kommunikacija [Language. Cognition. Communication], Moscow: Progress.

Van Dijk T. A. (2014) Diskurs i vlast': reprezentacija dominirovanija v jazyke i kommunikacii [Discourse and Power: Representation of Dominance in Language and Communication], Moscow: URSS.

Vincent R. C. (2000) A Narrative Analysis of US Press Coverage of Slobodan Milosevic and the Serbs in Kosovo. European Journal of Communication, vol. 15, no 3, pp. 321344.

Weber R. P. (1990) Basic Content Analysis, London: SAGE.

Woodrum E. (1984) "Mainstreaming" Content Analysis in the Social Science: Methodological Advantages, Obstacles, and Solutions. Social Science Research, vol. 13, no 1, pp. 1-19. 


\title{
Воображаемая дилемма «методология - методика», или Почему мы предпочитаем дискурсивный и нарративный анализ «традиционному» контент-анализу
}

\author{
Ирина Трочук \\ Доктор социологических наук, доцент кафедры социологии факультета \\ гуманитарных и социальных наук Российского университета дружбы народов \\ Адрес: ул. Миклухо-Маклая, д. 10/2, Москва, Российская Федерация 117198 \\ E-mail: irina.trotsuk@yandex.ru
}

В последние годы текстовый анализ стал весьма популярен как в социальных науках в целом, так и в социологии в частности в значительной степени вследствие «нарративного поворота», который подчеркнул неустранимость текстового измерения в социальных практиках и легитимировал их изучение через те дискурсы, что конституируют социальную реальность и идентификационные модели в современном обществе. Однако, хотя в арсенале социологии существует общеизвестный и институционализированный метод социологической интерпретации текстовых данных - контент-анализ, давно доказавший свою способность решать социологические задачи, предоставляя в наше распоряжение качественные и количественные данные о дискурсивно сконструированной социальной реальности, нынешняя тенденция популяризации текстового анализа в социологии связана отнюдь не с контент-анализом, а с размытыми многослойными методологическими подходами - нарративным и дискурсивным анализом. В статье сначала охарактеризованы три типа данных, с которыми сталкивается в эмпирической работе любой социолог, формализованные - их можно свести в матрицы данных и подвергнуть математической обработке; слабоформализованные, но все же четко структурированные и организованные; и неформализованные - они-то и требуют применения текстового анализа. Автор предлагает собственное объяснение нынешнего положения дел в сфере текстового анализа в социологии, суть которого сводится к тому, что зачастую нарративный и дискурсивный анализ позиционируются как единственно возможные исследовательские решения, как будто бы и не было нескольких десятилетий успешного применения контент-анализа. Данное объяснение объединяет две группы аргументов: меньшая по объему включает в себя ряд жестких требований, которые должен выполнять исследователь, работая методом контент-анализа; большая по объему состоит из заманчивых возможностей нарративного и дискурсивного анализа, обусловленных их происхождением, базовыми особенностями и междисциплинарным статусом.

Ключевые слова: текстовый анализ, текстовые данные, полу- и неформализованные данные, контент-анализ, нарративный анализ, дискурс-анализ, ограничения и возможности метода 